\title{
Increasing Financial Health through Casework Interventions
}

\author{
Thomas E. Smith (Correspondence) \\ Florida State University, USA \\ Kristin V. Richards \\ Mississippi Valley State University, USA \\ Victoria M. Shelton \\ Florida State University, USA
}

Received: June 11, 2015 Accepted: October 3, 2015 Published: October 11, 2015

doi:10.5296/ijsw.v2i2.7788 URL: http://dx.doi.org/10.5296/ijsw.v2i2.7788

\begin{abstract}
Given a need to increase clients' financial capability, social workers need a new set of techniques. Although financial education is a necessary service to increase financial capability, it is not enough. Practice models are needed to address the psychological and behavioral client needs that are exacerbated by inadequate financial management strategies. In this paper, six casework intervention models are discussed: motivational interviewing, harm reduction, marital and family therapy, dialectical behavior therapy, mindfulness training, and financial therapy. One model, the transtheoretical model, unites the six practice models. The need to validate casework interventions is essential through outcome research. Interventions not grounded in outcome research are speculative and may be misleading. A mixed model using quantitative and qualitative research techniques is proposed to build and evaluate casework intervention models.
\end{abstract}

Keywords: Financial health, Social work interventions, Outcome research

\section{Introduction}

Clients face an overwhelming number of obstacles in establishing a sustainable financial lifestyle. Structural factors in society prevent an easy exit from poverty. Clients mired in 
poverty face a lack of suitable education, poor nutrition, dangerous neighborhoods, and unemployment. These barriers defeat even the most determined clients. A lack of financial health is a product of debilitating societal factors.

Does the pursuit of financial health require a transformation of society? Until the jury is in on the question, stop-gap programs are needed. Efforts to combat financial illiteracy are needed to equip clients with a means of navigating an inhospitable society. Although services such psychotherapy and casework have been used to assist clients, newer services such as financial education are increasingly needed (Engelbrecht, 2008). Financial education addresses both earning and spending money. Volumes have been written on personal financial management especially around personal debt (e.g., credit card debt). Popular television celebrities have devoted their career in giving advice on personal financial management. Although such television celebrities provide viewers with helpful advice, it may also devolve into entertainment. Ironically, at least one charismatic and nationally known television personality, Suze Orman, provides financial advice and has a background as a social worker (Orman, 2007). Entertaining presentations are helpful in stimulating consumers' interest in financial management. However, financial education entails more than brief snippets of advice in primetime (Walker, 1996).

One challenge faced by consumers is that there is both too much and too little available information (Fox, Bartholomae, \& Lee, 2005). The sheer volume of material that confronts consumers is intimidating. Easily available trade books include those on personal financial planning (i.e., steps to planning, goal identification, behavior modification, and opportunity costs), money management (i.e., consumer behavior, budgeting and saving) taxes, saving and payment services, consumer credit, insurance, investing and retirement planning (Financial Literacy \& Education Commission, 2010).

In addition, consumers typically are urged to organize financial information such as insurance policies, mortgage/housing documents, tax returns and tax related documents, investment and retirement account statements, bills and receipts, as well as any warranties or service contracts (Gitman, Joehnk, \& Billingsley, 2011). It is not surprising that consumers quail at the demands being made to establish their financial Health.

Nor are pragmatics the only challenges being faced by consumers. Pragmatic concerns can be outweighed by intrapersonal and interpersonal factors (Devaney, Anong, \& Whirl, 2007; Walker, 1996). Knowing what to do does not always translate to behavior; a simple recitation of strategies to maximize wealth and minimize risk will not suffice. Rather, a comprehensive financial health approach is necessary (Johnson \& Sherraden, 2007). This requires recognition of opportunities, willingness to change, possession of skills and the ability to implement them. Perhaps, the best way to gain financial self-efficacy is to implement casework interventions that promote financial health (Lapp, 2010).

\section{Types of Financial Health Casework Interventions}

In this paper, different casework interventions will be presented including Transtheoretical Models, Motivational Interviewing, Dialectical Behavior Therapy, Harm Reduction, Marital and Family Therapy, Mindfulness Training, Financial Therapy, and self-help books and community resources. Each intervention model has a different focus. One model that cuts 
across intervention models is the Transtheoretical Model (Xiao, Newman, Prochaska, Leon, Bassett, \& Johnson, 2004a; Xiao, O’Neill, Prochaska, Kerbal, Brennan, \& Bristow, 2004b). The authors proposed that there are several stages of change. In their formulation, changes only occur when clients are ready to make such changes. They posit that there are multiple levels of change: Precontemplative, Contemplative, Preparing, Action, and Maintenance. Clients who are reluctant to address faulty financial behaviors and accept financial therapy are in a precontemplative stage of readiness (Kerkmann, 1998).

Such clients may deny that they need assistance in addressing finances; however, such denials also fly in the face of the damning evidence against them. How to move past such denials is never an easy task. The literature on drug addictions may provide insight on such intransigent behavior. It suggests that there are significant levels of denial within a precontemplative stage of readiness for change (Garrett, Landau-Stanton, Stanton, \& Stellato-Kabat, 1997). Addressing such denial requires patience and vigilance to find an optimal time to intervene. Given this level of readiness, a pedagogical approach is not likely to be effective. A simple recitation of strategies of personal finance management will not be accepted by a client who is in a precontemplative stage of change (Xiao et al., 2004a; Xiao et al., 2004b). Moving clients through stages of readiness requires artful casework interventions. Although clients may be initially reluctant to reduce or abstain from risky behavior, they become increasingly open to change as their readiness increases. Different casework interventions increase different levels of readiness to change. In a precontemplative stage of readiness, clinicians will need to implement Motivational Interviewing (Miller \& Rollnick, 2002). This form of intervention requires a stepwise approach to begin the process of reducing and abstaining from risky or negligent financial behavior.

Motivational Interviewing (MI) is characterized by eliciting cooperation from clients versus demanding it. The approach stresses clients' self-determination in terms of resolving their ambivalence. In this adaptation of motivational interviewing, instructors elicit a discussion of ambivalence to adopt financial discipline. The ambivalence stems from anxiety caused by the realization of the changes required to adopt a financially disciplined lifestyle. Direct persuasion or confrontation is not part of motivational interviewing techniques. In motivational interviewing, consumers and the financial counselors are portrayed as partners in solving problems.

The differences between motivational interviewing and standard educational programs are significant. MI relies on self-determined and jointly articulated plans to reduce and abstain from financially risky behaviors. By contrast, educational programs rely on a pedagogical presentation. Persuasion is frequently a part of standard educational programs but is eschewed in MI. Adherents of MI reject assumptions that education can remediate risky decision making.

Success during the initial stages of MI results in a beginning commitment to change behavior. In this case, the behavior being changed is financially imprudent decision-making. Success during the contemplative stage or the second stage results in the consumer articulating the need for change. Because increased motivation is achieved in this goal, it permits forward action in planning toward planning. During the planning stage, the consumer plans the strategy by which financial troubles can be alleviated. Such planning is essential for there to 
be effective use of readily available financial counseling resources. Use of the stepwise strategy embodied by the transtheoretical model allows for seamless progression in motivation and in behavior change.

A related treatment model, Dialectical Behavior Therapy (DBT) also has applicability to teaching financial health and addresses financial crises. It is increasingly popular in addressing intransigent clinical problems (Linehan, 1993; Venheul et al., 2003). Much like MI, it eschews a pedagogical approach, and provides consumers with dialectic of change in their lifestyle. Dialectics of change bring clients to a "tipping point" of decision making. At this point, "change/no change" ispresented as viable options for consumers. Demands for clients to change may well create a push back resulting in a return to financially ruinous behaviors. Focusing on the emotional consequences of financial problems may only reinforce them. Rather, a mixture of change/no change message is preferable. This type of dialectic in DBT allows clients to be relieved of oppressive pressure to change while at the same time encouraging it to happen.

Dialectical Behavior Therapy combines validation and skills training. The validation assists clients to change a defeated and pessimistic mindset while the training provides the skills to make meaningful improvements in their lives. Not surprisingly, clients need both components to make lasting improvements in their lives. With financial crises, DBT is useful in challenging clients to change a profligate lifestyle without becoming judgmental or harshly critical. By learning essential financial literacy skills and changing self-defeating mindsets, clients have the tools to increase their financial health.

An approach related to DBT is financial coaching (Collins, 2010). It is more akin to augmenting what already is being done versus a standalone approach. It uses the same kind of encouragement to resolve consumers' ambivalence as does motivational interviewing. Because encouragement is focused more on simply recounting the continued success, there is a minimal focus on moralistic homilies. This model's focus on dialectics, minimal amounts of persuasion and moralism, and avoiding problem statements makes this model a useful adjunct to DBT.

Success during the action and maintenance stages results in consumers implementing a new financial strategy and then maintaining it. During the action stage, consumers can make autonomous use of educational materials on financial health. However, achieving an action stage of readiness is no substitute for coping with unforeseen pitfalls. Poor financial behaviors stemming from a lack of knowledge still abound. Clever sales tactics can deceive even the most experienced of consumers. The perils of ineffective activities still exist. Because errors of judgments will always exist, methods for harm reduction are also necessary (Marlatt, 1998).

As consumers are empowered to manage their finances, they develop a sense of financial efficacy (Lapp, 2010). This term is derived from classical discussions of self-efficacy (Bandura, 1977). Financial efficacy is necessary to cope with potential downturns in personal fortunes. Because they can be devastating to initial stages of changing financial lifestyles, financial efficacy is essential in staying the course. Maintaining change may in fact be as difficult as implementing the change. Without a sense of efficacy, maintaining change may not be possible. Harm reduction requires the presence of competent counselors who will work 
with newly financially capable clients to restructure financial lifestyles. Because many difficulties are caused by exigent societal circumstances, creative problem solving is necessary. One key consideration is whether to increase wealth or to reduce debt. Advice on which avenue to take is not always clear. It may be easier to gain wealth than to reduce expenditures. On the other hand, it may be a losing proposition to increase wealth to stem an increasingly ruinous debt load caused by paying fees and interest on loans and credit card balances. Thus, working harder may not be working smarter. Although there are many strategies to reduce debt, it is likely that financially troubled consumers will have to change their entire lifestyle.

Mindfulness has been used in changing lifestyles. For example, addiction has long been considered more of a pervasive lifestyle than a discrete clinical manifestation (Jacobs, 1986). Mindfulness in its traditional form consisted of different forms of meditation. It has been used extensively in clinical populations such as borderline personality disorders (Rizvi, Welch, \& Dimidjian, 2009). Mindfulness allows patients to observe, describe, and participate in decision making (Shapiro, Carlson, Astin, \& Freedman, 2006). Mindfulness applied to personal finance works against impulsive, irrational spending behaviors (Brown, Kasser, Ryan, Linley, \& Orzech, 2009). Just as indulging in a surfeit of comfort food is dangerous to both physical and emotional health, needless spending has similar consequences on a person's financial health. Because mindfulness allows focused and planful behavior that maximizes positive outcomes, it prevents "comfort purchases." By promoting tolerance of distress and uncertainty, it allows consumers to avoid needless purchases (Smith, Richards, \& Shelton, 2015).

Its importance to people is not only in psychiatric syndromes but also in financial decision-making. One theory, behavioral economics, explains why mindfulness is so important at the precontemplative level. Behavioral economics suggests that consumers are seemingly irrational and will not ordinarily act to maximize their personal finances (Thaler \& Sunstein, 2009). Their irrationality stemsfrom the unwillingness to act on knowledge about financial management.

Working against rational behavior are all too human emotions such as greed, impatience, and/or financial need. Hoping that education on imprudent credit card use will be sufficient is naive. Because mindfulness promotes focused and planful behavior, impulse buying for unneeded items is significantly diminished. In part, it is effective against impulsive purchases because it promotes pausing before acting. This pause may be all that is necessary to be planful. In part, the pause creates a "calm" before the "storm" of urgent purchases.

Two other theories or models show why mindfulness is necessary. The need to protect against impulsive purchases is highlighted in these theories. One is known as "satisficing" (Simon, 1956). Satificing theorists are critical of the behavioral patterns adopted by people whose inclination is to search frantically (maximizing) for a "deal." The end goal is to locate an item whose price is lower in one store than others. However, the endless vigilance to purchase an item may obscure the importance of the item itself. In short, the "thrill of the chase" may outweigh the intrinsic value of the item itself. In fact, the thrill may detract from a previously established plan.

On the other hand, satificing refers to the approach in which the consumer believes that the 
price of the item is "good enough," negating the need for an endless chase. Sometimes, good enough is enough (cf. Brown et al., 2009). Adopting this value aids in the establishment of a planful and focused financial lifestyle. A similar model also guides consumers to a modest financial lifestyle. Here, the irony is that "less is more." This model stresses the advantages of a simple lifestyle devoid of the complexity that is caused by juggling personal debt incurred by unwise credit card use.

For example, living a credit card-free lifestyle severely limits purchasing items or other lifestyle activities. On the other hand, it promotes more appreciation of what is purchased or done. Voluntary simplicity engenders a lifestyle that is healthier and more productive (cf. Robertson, 2005) than its profligate counterpart. And it is also consonant with the benefits accrued from mindfulness casework interventions. Simplicity that limits needless complexity promotes focused and planful financial decision-making.

Another variable is critical in assessing and promoting financial health. It is difficult for people to act autonomously when they are in a committed relationship (i.e., spouse or partner). In fact, the resolve of one person can be easily diminished given intractable behavior by his or her partner. It may be asking too much for one person to cope with the refusal of his/her partner to engage in a different financial lifestyle. To assist the partner seeking to start a new financial lifestyle may require marital and family casework interventions. Little has been done to study this form of intervention although it represents a pervasive issue throughout marital and family therapy (Britt, Huston, \& Durband, 2010). In fact, two studies on accredited marital and family therapy programs document the lack of financial health coursework in their curricula (Durband, Britt, \& Grable, 2010; Poduska \& Allred, 1990).

This absence is unfortunate. Many classic family therapy models are derived from family systems theory. It outlines the dilemma present within committed relationships. Coercive dyadic relationships involve either a voluntary or involuntary "push-pull" between the two partners. Traditional family systems rely on communication patterns between members of a family unit, which includes parents, or at least members of committed relationships. Conflictual discussions about financial affairs may simply be one facet of a troubled relationship (Aniol, 1997).

Traditional family systems-based therapy can be used to ease the conflict and by doing so resolve conflicts about finances. These therapies include but are not limited to the models espoused by Murray Bowen, Salvador Minuchin, or Jay Haley (Nichols, 2010). Of course, the specific model chosen depends on the nature of the conflict. For example, if the conflict centers on patterns of expenditure in families of origin, some form of family systems therapy (i.e., Bowenian) is needed. On the other hand, if the conflict appears to be a symptom errant family development, then a strategic intervention is the best approach. But if the conflict centers on some form of hierarchical conflict, then Minuchin's intervention should be pursued (cf. Nichols, 2010).

Related to family therapy methods are those used in marital therapy. One such model is emotion-focused therapy. It was proposed by Susan Johnson (2004) and used in marital conflict. They believe that conflict based on troubled marital relationships is based on extant emotional schema. This type of marital therapy is based on attachment theory. As such, finances depend more on emotional reactions between partners than any consideration of 
maximizing financial gain.

Financial conflicts based on family or marital interactions suggest that simple advice to remedy unwise financial strategies will not be effective. Although a lack of information may contribute to risky behavior, it is only the tip of the iceberg of financial problems. For many couples, discussions of money are a direct proxy of marital conflict. Greenberg and Johnson's (1988) intervention with conflictual couples directly addresses their emotional bonds. By so doing, the role of any marital conflict is revealed.

For Johnson (2004), marital bonds are attachment bonds. In her conceptualization, attachment is developed over time within a marital (or committed relationship) relationship. If the emotional needs of each partner are met in that relationship, the bonds and attachment grow stronger. Emotions are therefore both the agent and target of change. Emotions are the agents in that focusing on emotional bonds allow resolution of conflict. Emotions are the targets in that emotional schema need to be changed for each party to be able to be in relationship with each other. It may not be an overstatement to say that money is an emotional surrogate. To talk about emotions is to talk about money.

The theoretical orientations presented here may be integrated into Financial Therapy, a comprehensive method to addressing financial concerns of individuals, couples, and families. Financial Therapy addresses psychological, sociological, and behavioral areas of finance (c.f. Smith, Shelton, \& Richards, 2014; Smith, Shelton, \& Richards, 2015). Recognizing that a "one-size-fits-all" approach is inappropriate, an integrative financial therapist may utilize a client-centered approach to focus on client needs and preferences. Through a blend of financial management techniques and therapeutic casework interventions, clients gain a greater understanding of the role of personal finance in their lives.

Within financial therapy, an examination and prioritization of wants and needs and inspection of spending habits and heuristics is followed by efforts to create budget that incorporates financial goals. In the Smith et al's $(2014 ; 2015)$ model, Successful completion of financial therapy includes the development of a Black Line budget that serves as a financial mirror, reflecting the client's financial identity. As conceptualized by Smith et al. (2014), this approach to addressing money concerns works best for clients in the contemplative stage, moving them through the action stage, and preparing them for maintenance stage that includes inevitable mishaps.

The paper began with a discussion of the stages of change with a caveat that educational presentations are most effective when families are in the action phase. The authors would be remiss if they did not discuss traditional financial education products. First, there are popular self-help books written by television personalities. Second, there are websites, many sponsored by respected companies and publications, which provide guidance and software in planning and maintaining sound financial decision-making. Third, there are online and community-based workshops and courses that provide information on personal finances.

Popular self-help books on personal finance fill up shelves at bookstores. In fact, the number of books on personal finance is overwhelming for consumers seeking advice. Charismatic authors who cite anecdotes of dramatic improvement make extravagant claims. The authors' charisma undoubtedly makes the message of financial prudence more effective (cf. Howard 
\& Meltzer, 2001; Orman, 2007; Ramsey, 2007). Although much can be made about celebrating charisma that promotes prudence, replicating the results may be difficult. In part, the books may obscure the distinction between entertainment and education. The limitations of these self-help books stems from the variables mentioned earlier in this paper. Consumers who are in the precontemplative stage are unlikely to read books on making dramatic changes; more likely is an avoidance of such texts. Absent the charismatic medium, the message is lost.

A contemporary approach to personal finance is through websites aimed at consumers seeking advice and/or guidance to make prudent decisions. For consumers comfortable with navigating websites, this approach is an attractive option to reading books. Creating budgets, consolidating financial information and giving practical methods to maximize wealth are typically provided. Although the information is comprehensive and helpful, they are not interactive. This lack of a "personal" touch makes them impersonal and unable to solve idiosyncratic problems.

Websites may err on being either superficial or complex. Superficial websites are not helpful because of their lack of detailed information. On the other hand, complex websites are intimidating because they may require any form of financial calculations. This is less a fault of the websites and more a reality of what can be expected from impersonal, anonymous sources of information. Whether user-friendly (e.g., Get Rich Slowlyhttp:/www.getrichslowly.org) or authoritative (e.g., CNNMoneyhttp://money.cnn.com/), websites are akin to online books with computer-driven interactions.

A final approach comes in the form of community presentations such as those offered by Robert Kiyosaki or Dave Ramsey. These workshops and community presentations provide needed information. However, the very nature of these offerings only provides superficial assistance. In short, community presentations come with their own dangers. The dilemma is knowing how to choose the most helpful community resource.

\section{No Easy Answers}

The inability to navigate through options to achieve financial health undoubtedly renders consumers uncertain of the best course of action. One consequence of such uncertainty is diminished financial efficacy. Without a secure knowledge of financial options, consumers lack the ability to make prudent decisions. Without such knowledge, consumers are at risk.

However, speculations on effective financial counseling methods are endemic in trade books and academic journals. However, such speculation is akin to a financial counsel that is not grounded in actual outcomes. Still, it is not easy to document the efficacy or effectiveness of financial casework interventions. Good intentions and a basic knowledge of research methods seldom suffice to arrive at credible conclusions about financial casework interventions (Collins \& O'Rourke, 2010).

A listing of casework interventions does not resolve difficulties in knowing which ones should be chosen under which situations. Although there may be intuitive reasons to choose one approach more so than another, a lack of evidence can make the choice costly in terms of time and money. The situation is akin to one that is encountered by anyone who is trying to 
choose some type of helping interventions such as marital and family therapy, psychotherapy, or psychoeducation.

The gold standard of ascertaining efficacy or effectiveness is a randomized clinical trial (RCT). The science of intervention research is broad and well beyond the scope of this paper. It is safe to say that successful RCTs require a significant expenditure of time and money.

An iterative model of process-outcome research is one promising methodology (Sells, Smith, \& Sprenkle, 1995). In this model, the researcher starts with a qualitative study such as an ethnography. This research model focuses on the context of an event. In intervention research, the context is the process of treatment whereas the outcome consists of a measurement of change. Thus, the researcher starts by conducting ethnographies of the treatment personnel within the context of the treatment agency. Clients are also included in this study. Once completed, the researcher has gathered a holistic sense of the "who, what, where, and why" of treatment. Armed with this information, the researcher can start an outcome study with an understanding of the reasons why change occurs. The assumption is that if change did not occur, the researcher would understand the moderators of the treatment effort.

Such an iterative methodology provides policy makers and scholars with explanations on which financial responsibility programs are effective and why (i.e., mediating factors). The accompanying process will provide insights into what moderates the efficacy of the responsibility programs. Because it is unlikely that sweeping outcome studies on financial education will be conducted, modest pilot studies are a useful beginning. They provide an understanding of where to begin in planning for elaborate outcome studies.

\section{Discussion}

The last several decades have shown the need for consumers to fend for themselves against financial predators. The appalling financial losses experienced by all sectors of society have shown the need for development of astute educational approaches to promote financial health. As this paper has argued, financial health casework interventions are diverse and address different consumer needs. Casework interventions are of different duration, intensity, focus, and purpose. It is safe to say that educational efforts provided by books, classes, websites, or therapists, are characterized by their diversity. Without efforts to teach and research education on financial health, the diversity will continue to fragment efforts to help consumers defend themselves. The ability for consumers to regain financial stability will require multi-faceted casework interventions for individuals and their families. Finally, it will require intervention researchers to conduct both pilot and substantive studies to unravel what combination of approaches will be effective with which consumer groups.

\section{References}

Bandura, A. (1977). Self-efficacy: Toward a unifying theory of behavioral change. Psychology Review, 84(2), 191-215. http://dx.doi.org/10.1037/0033-295X.84.2.191

Boshara, R., Gannon, J., Mandell, L., Phillips, J. W. R., \&Sass, S. (n.d.). Consumer trends in the public, private and nonprofit sector. Retrieved from http://www.nefe.org

Brown, K. W., Kasser, T., Ryan, R. M., Linley, P. A., \& Orzech, K. (2009). When what one has is enough: Mindfulness, financial desire discrepancy, and subjective well-being. Journal of Research in Personality, 42(5), 727-736. http://dx.doi.org/10.1016/j.jrp.2009.07.002 


\section{Macrothink Institute ${ }^{T M}$}

Collins, J. M. (2010). .A review of financial advice models and the take-up of financial advice. Retrieved from http://cfs.wisc.edu/Working_Papers/A_Review_of_Financial_Advice_Models_and_Take-Up _of_Financial_Advice_WP_10-5.pdf

Collins, J. M., \& O'Rourke, C. M. (2010). Financial education and counseling-still holding promise. Journal of Consumer Affairs, 44(3), 483-498. http://dx.doi.org/10.1111/j.1745-6606.2010.01179.x

CNN Money. (2011). Retrieved from http://money.cnn.com/

Devaney, S. A., Anong, S. T., \& Whirl, S. E. (2007). Household savings motives. The Journal of Consumer Affairs, 41(1), 174-186. http://dx.doi.org/10.1111/j.1745-6606.2006.00073.x

Durband, D. B., Britt, S. L., \& Grable, J. E. (2010). Personal and family finance in the marriage and family therapy domain. The Journal of Financial Therapy, 1(1), 7-22. http://dx.doi.org/10.4148/jft.v1i1.242

Engelbrecht, L. (2008). The scope of financial literacy education: A poverty alleviation tool in social work? Social Work/MaatskaplikeWerk, 44(33), 252-262.

Financial Literacy \& Education Commission. (2010). My Money. Gov. Retrieved from http://www.mymoney.gov/index.html

Fox, J., Bartholomae, S., \& Lee, J. (2005). Building the case for financial education. The $\begin{array}{llll}\text { Journal of Consumer } & \text { Affairs, } & 39(1), & \text { 195-214. }\end{array}$ http://dx.doi.org/10.1111/j.1745-6606.2005.00009.x

Garrett, J., Landau-Stanton, J., Stanton, M. D., Stellato-Kabat, J., \& Stellato-Kabat, D. (1997). ARISE: A method for engaging reluctant alcohol- and drug-dependent individuals in treatment. Journal of Substance Abuse Treatment, 14(3), 235-248. http://dx.doi.org/10.1016/S0740-5472(96)00159-6

Get rich slowly: Personal finance that makes sense. (2011). Retrieved from http://www.getrichslowly.org/

Gitman, L. J., Joehnk, M. D., \& Billingsley, R. D. (2011). Personal financial planning. Ohio: South-Western Cengage Learning.

Greenberg, L. S., \& Johnson, S. M. (1988). Emotionally focused therapy for couples. New York: Guilford.

Howard, C. \& Meltzer, M. (2001). Get Clark smart: The ultimate guide to getting rich from America's money-saving expert. New York: Hyperion.

Jacobs, D. F. (1986). A general theory of addictions: A new theoretical model. Journal of Gambling Studies, 2(1), 15-31. http://dx.doi.org/10.1007/BF01019931

Johnson, E., \& Sherraden, M. S. (2007). From financial literacy to financial capability among youth. Journal of Sociology \& Social Welfare, 34(3), 119-146.

Johnson, S. M. (2004). The practice of emotionally focused couple therapy. New York: Brunner/Routledge ( $2^{\text {nd }}$ Ed.).

Kerkmann, B. (1998). Motivation and stages of change in financial counseling: An application of a transtheoretical model from counseling psychology. Financial Counseling and Planning, 9(1), 13-20. 
Kiyosaki, R. (2011). Learn to be Rich. [Community Presentation].United States: Rich Dad Operating Co.

Linehan, M. M. (1993). Cognitive-behavioral treatment of borderline personality disorder. New York: Guilford Press.

Marlatt, G. A. (1998). Harm reduction: Pragmatic strategies for managing high-risk behaviors. New York: Guilford Press.

Miller, W. R., \& Rollnick, S. (2002). Motivational interviewing: Preparing people to change addictive behavior (2nd Ed.). New York: The Guildford Press.

Orman, S. (2007). Women \& money: Owning the power to control your destiny. New York: Spiegel \& Grau.

Poduska, B., \& Allred, G. H. (1990).Family finances: The missing link in MFT training. The American Journal of Family Therapy, 18(2), 161-168. http://dx.doi.org/10.1080/01926189008250800

Prochaska, J. O., \& DiClemente, C. C. (1984). The Transtheoretical Approach: Crossing traditional boundaries of change. Dorsey Press, Homewood, IL.

Ramsey, D. (2007). The Total Money Makeover: A proven plan for financial fitness. Nashville: Thomas Nelson.

Ramsey, D. (2011).Dave Ramsey's Total Money Makeover LIVE! [Community Presentation]. United States: The Lampo Group.

Rizvi, S. L., Welch, S. S., \& Dimidjian, S. (2009). Mindfulness and borderline personality disorder. In F. Didonna (Eds.), Clinical handbook of mindfulness. New York: Springer. http://dx.doi.org/10.1007/978-0-387-09593-6_14

Robertson, J. (2005). The new economics of sustainable development: A briefing for policy makers.

http://www.jamesrobertson.com/book/neweconomicsofsustainabledevelopment.pdf

Robertson, J. (2005). The new economics of sustainable development: A briefing for policy makers.

from

http://www.jamesrovertson.com/book/neweconomicsofsustainabledevelop.pdf

Sells, S. P., Smith, T. E., \& Sprenkle, D. (1995). Integrating quantitative and qualitative research methods: A research model. Family Process, 34, 1-20. http://dx.doi.org/10.1111/j.1545-5300.1995.00199.x

Shapiro, S. L., Carlson, L. E., Astin, J. A., \& Freedman, B. (2006). Mechanisms of mindfulness. Journal of Clinical Psychology, 62, 373-386. http://dx.doi.org/10.1002/jclp.20237

Simon, H. A. (1956). Rational choice and the structure of the environment. Psychological Review, 63(2), 129-138. http://dx.doi.org/10.1037/h0042769

Shumway, S. T., Bagwell, D. C., \& Bell, M. M. (2005). Using stages of change and motivational interviewing models to encourage retirement and financial planning. Journal of Retirement Planning, 8(4), 39-51.

Smith, T. E., Richards, K. V., \& Shelton, V. M. (2015). Mindfulness in financial literacy. Journal of Human Behavior in the Social Environment. 


\section{Macrothink}

International Journal of Social Work

ISSN 2332-7278

2015, Vol. 2, No. 2

Smith, T. E., Shelton, V. M., \& Richards, K. V. (2014). More than numbers: Everyday financial therapy. Seattle, WA: Southeastern Professional Books

Smith, T. E., Shelton, V. M., \& Richards, K. V. (2015). More than numbers: Facilitator's guide to everyday financial therapy. Seattle, WA: Southeastern Professional Books

Smith, T. E., Shelton, V. M., Richards, K. V., Malespin, T., \& Nelson, R. J. (2015). Sirens' call: Understanding poor financial decision-making and credit card misuse. Journal of Human Behavior in the Social Environment, 25(8), 897-906. http://dx.doi.org/10.1080/10911359.2015.1039156

Thaler, R. H., \& Cass, R. S. (2009). Nudge: Improving decisions about health, wealth, and happiness. New York: Penguin.

Verheul, R., van den Bosch, L.M.C., Koeter, M.W.J., de Ridder, M.A.J., Stijnen, T., \& van den Brink, W. (2003). Dialectical behaviour therapy for women with borderline personality disorder: 12-month, randomised clinical trial in the Netherlands. British Journal of Psychiatry, 182, 135-140. http://dx.doi.org/10.1192/bjp.182.2.135

Walker, C. M. (1996). Financial management, coping and debt in households under financial $\begin{array}{llllll}\text { strain. Journal of Economic } & \text { Psychology, } & 17, & \text { 789-807. }\end{array}$ http://dx.doi.org/10.1016/S0167-4870(96)00036-0

Xiao, J. J., Newman, B. M., Prochaska, J. M., Leon, B., Bassett, R., \& Johnson, J. L. (2004a). Applying the transtheoretical model of change to debt reducing behavior. Financial Counseling and Planning, 15(2), 89-100.

Xiao, J. J., O’Neill, B., Prochaska, J. M., Kerbal, C. M., Brennan, P., \& Bristow, B. J. (2004b). A consumer education program based on the transtheoretical model of change. International $\begin{array}{llll}\text { Journal of } & \text { Consumer } & \text { Studies, } & \text { 28(1), }\end{array}$ http://dx.doi.org/10.1111/j.1470-6431.2004.00334.x

\section{Copyright Disclaimer}

Copyright reserved by the author(s).

This article is an open-access article distributed under the terms and conditions of the Creative Commons Attribution license (http://creativecommons.org/licenses/by/3.0/). 